\title{
Monoclonal Antibody BrE-3
}

National Cancer Institute

\section{Source}

National Cancer Institute. Monoclonal Antibody BrE-3. NCI Thesaurus. Code C1938.

A murine and humanized monoclonal antibody that targets epitopes of epithelial

glycoprotein mucin (MUC-1) on breast cancer surfaces. ( $\mathrm{NCl}$ ) 